\title{
平面型のコイル渦電流探傷法の最適設計に関する考察
}

\section{A study of optimized design of the flat type $\infty$ eddy current sensor}

\author{
丸山公希 ${ }^{* 1}$ (学正員)，齊藤兆古 ${ }^{* 1}$ (正員)
}

\author{
Kouki MARUYAMA (Stu. Mem.), Yoshifuru SAITO (Mem.)
}

\begin{abstract}
Previously we have succeeded in developing the ECT sensor called "Flat $\infty$ coil". This sensor is improved of the $\infty$ coil which is developed by our laboratory in 2013. Flat $\infty$ coil sensor is composed of the two spiral type exciting coil and one sensing coil. This sensor is so high sensitive and has the versatile capability e.g. it is able to detect the not only flat surface defect but also curved surface defect compared with conventional $\infty$ coil.

This paper concerns with an optimization of the flat $\infty$ coil. Optimization of this flat $\infty$ coil fully depends on the $3 \mathrm{D}$ finite elements methods. According to the 3D finite element simulation results, we have successfully carried out the optimum size of two exciting coils and a sensing coil.
\end{abstract}

Keywords: Eddy current testing, Non-destructive testing, Flat $\infty$ coil, Optimization.

\section{1 緒言}

現代の文明社会を支えるのは人類の踥智が創造した 多くの文明の利器による。例えば,高速な移動手段を提 供する高速鉄道, 自動車, 航空機, そして,電力生成・系統 システム,照明システム,セキュリティシステムなど,い わゆる産業プロダクトから鉄橋, 大型ビルや高速道路 などの社会的インフラストラクチャまで広汎で多岐に 渡る文明の利器が存在し, 人類の文明生活を支えてい るのは自明であろう。

産業プロダクトから社会的インフラストラクチャに いたる文明の利器の多くは何らかの形で機械的構造を 持ち,強度や形状維持のフレームが存在する。機械的構 造の強度や形状を維持するフレームの多くは金属材料 からなり,それぞれの産業プロダクトの機能を維持す るため,機械的ストレスを受け続けている。産業プロダ クトの中で,人間の大量輸送に関わる大型バス, 高速列 車,大型旅客機のみならず原子力発電所で代 Table.され る大規模エネルギー変換システムなどのプラントや社 会的インフラストラクチャ設備では,機械的ストレス だけでなく熱忘力,中性子による劣化などがある。当然 であるが,これらの産業プロダクトではフレームの健 全性が高度な信頼性,安全性を確保するために極めて 重要な要素である。

連絡先：丸山 公希， $\bar{\top} 184-8584$ 小金井市梶野町 3-7-2, 法政大学大学院工学研究科電気工学専攻齊籐兆古研究室, e-mail: kouki.maruyama.8n@stu.hosei.ac.jp

${ }^{* 1}$ 法政大学大学院理工学研究科電気電子工学専攻
金属の健全性を確保する手段として最も基幹的で重 要な技術が金属材料に対する非破壊検査技術である。 金属の非破壊検査法として,渦電流探査法(Eddy Current Testing, 以後,ECT と略記), 電気ポテンシャル法,超音波 影像法およびX線断層撮影法のような様々な方法があ る。この中で,金属の非破壊検査として,ECT による方 法は,検査対象と直接接触の必要がなく,比較的簡単な 装置で高速な検査が可能である(1-3)。このため,ECT は 自動車の個々の部品検查から橋梁の劣化検査など極め て多くの分野で広汎に使われている。これは,人類の創 造する文明の利器の力学的強度維持は大部分が導電性 を有する金属材料からなるためであり,特に ECT は選 択的に非接触で金属部分のみ検査可能である点に拠る。

2013 年, 我々の研究室で新型渦電流センサ・ハコイル が開発された[5]。この ECT センサは従来のセンサに 対して,高感度かつ高いリフトオフ特性を有するが,そ のセンサの構造上,曲面の被検査対象に対しては感度 が低下する欠点がある。この問題点を解決するべく， のコイルの特性や構造を活かしつつ,曲面を有する検 査対象の欠損探査を可能とするフレキシブルな平面型 のコイルを提案した。結果として曲面のみならず平面 の欠損に対しても従来ののコイルを上回る感度を有す るセンサの開発に成功した。

本論文は，平面型めコイルセンサの最適設計に関す るものである。平面型めコイルはスパイラル状に巻か れた励磁コイルと有限長ソレノイド型の検出コイルか ら構成され, 検出感度は各コイルの大きさに依存する。 
形状の最適設計には，大前提として励磁コイルおよび 検出コイルの高さを一定值に固定する。励磁コイルの 直径を基準とし，励磁コイル間の距離（これにより検 出コイルの長さが一意的に決まる）および検出コイル 長を変化させた時の検出感度を有限要素法により算出 する。各形状での計算結果から励磁コイル間の距離と コイル長さの近似関数を導出し最適值を求める。よっ て, 本論文は全ての試行計算結果から近似関数を求め るため, 試行計算結果を無駄にすることがない最適設 計の方法とその実例を紹介寸る。

\section{2 平面型のコイル}

\section{1 平面型のコイルの構造}

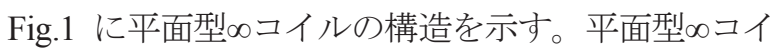
ルは二個の励磁コイルと Fig.1(b)に示すようなコアに 磁性体を持つ検出コイルから構成されている。検出コ イルの巻線軸は二個の励磁コイルの中心点を結ぶ線と 垂直となるようになっている。我々はこの形状から“䛲 コイル”と呼ぶ。

3 次元の有限要素法を用いて二個の励磁コイルを隣 り合う位置に配置し, 互いに逆位相の電流を流してシ ミュレーションを行う。励磁電流により生じる磁界分 布は逆の極性を持ちループ状に形成されるため, Fig.2 のように二個の励磁コイルの間には磁界がゼロまたは 極めて小さい值となる部分が生まれる。コアにフェラ イトなどの磁性体を持つ検出コイルを二個の励磁コイ ル間に励磁コイルの面に対し垂直な方向に設置する。 検出コイルの面が励磁コイルによって生じる磁界と常 に平行となるため検出コイルには誘起電圧が発生しな い。更に磁界が極めて小さい部分に配置されることに より検出コイルが持つ磁性体の影響が少なく, 元の磁 界分布を乱さない設計となっていることが Fig.2 から わかる。

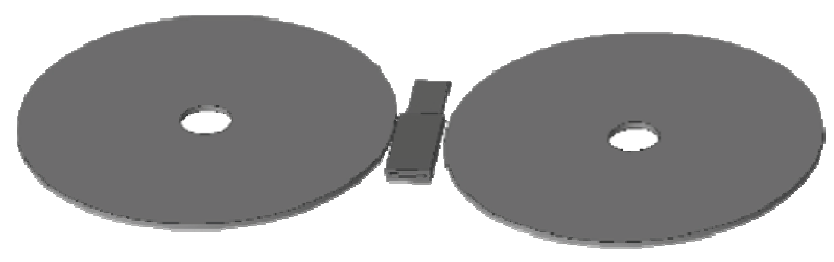

Fig.1 Structure of the flat $\infty$ coil where circulate coils on both side are the exciting coils and rectangular box is the sensing coil wound around edge of the ferrite bar.

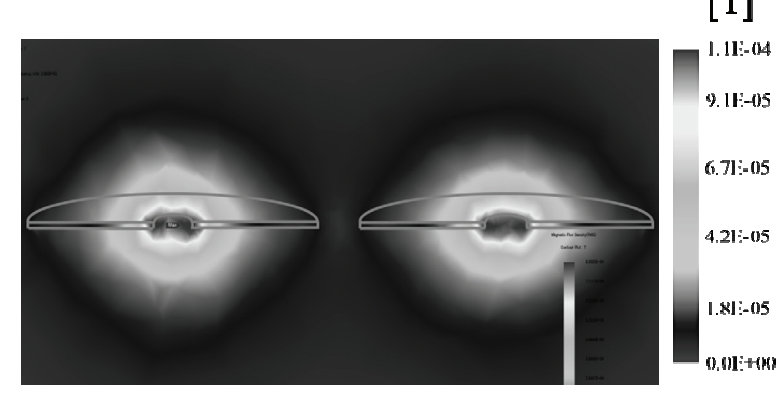

Fig.2 Magnetic flux intensity distribution.

\section{2 平面型œコイルの動作原理}

のコイルを健全な被検查対象上に設置した場合, 被 検查対象中には励磁電流の逆方向に渦電流が流れる。 被検査対象中の渦電流によって生じる磁束は検出コイ ルの面に対し平行成分となるため誘起電圧は発生しな い。しかし, 被検查対象中に欠損が存在する場合, 欠 損を迂回するように流れる渦電流が発生し，検出コイ ルの面に対し垂直な磁束成分が発生する。このため検 出コイルに誘起電圧が発生し， 久損の有無を識別する ことが可能となる。

Fig.1 に示す平面型のコイルの動作原理を検証する ために株式会社 JSOL の 3 次元有限要素法パッケージ JMAGを用いてシミュレーションを行う。Table.1 に励 磁コイルと検出コイルの諸定数を示す。平面型めコイ ルは縦 $100 \mathrm{~mm}$, 横 $200 \mathrm{~mm}$, 厚さ $1 \mathrm{~mm}$ の銅板上に配置 され, 久損が無い場合, 検出コイルの巻線軸に対し欠 損が 0 度, 90 度, 45 度の場合で計算を行う。また Table.1 に示すように励磁コイルには実効值 $300 \mathrm{~mA}$, 周波数 $256 \mathrm{kHz}$ の正弦波電流を励磁電流とし通電した。

Fig.3 はそれぞれ銅板上に流れる渦電流と検出コイ ルのフェライトコア内の磁束密度分布を示している。

Table.1 Various constants used in the 3D simulation.

\begin{tabular}{lr}
\hline \multicolumn{2}{c}{ Exciting coil } \\
\hline Coil outer diameter & $30 \mathrm{~mm}$ \\
Coil inner diameter & $10 \mathrm{~mm}$ \\
Coil length & $0.4 \mathrm{~mm}$ \\
Number of turn & 20 \\
Input current(effective value) & $300 \mathrm{~mA}$ \\
Frequency & $256 \mathrm{kHz}$ \\
\hline \multicolumn{2}{c}{ Sensin coil } \\
\hline Coil outer diameter & $1.4 \mathrm{~mm} \times 2.4 \mathrm{~mm}$ \\
Coil inner diameter & $1 \mathrm{~mm} \times 2 \mathrm{~mm}$ \\
Coil length & $6 \mathrm{~mm}$ \\
Number of turn & 100 \\
Axis core & $\mathrm{MnZn} / \mathrm{ferrite}$ \\
& (permiability:3000) \\
\hline
\end{tabular}



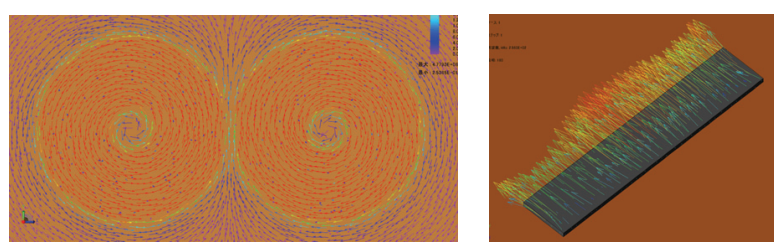

(a) No defect
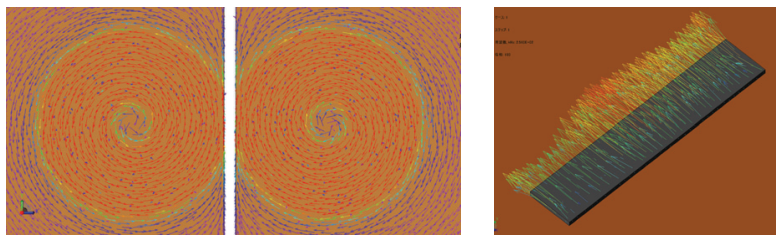

(b) 0 degree defect to the two adjacent exciting coils
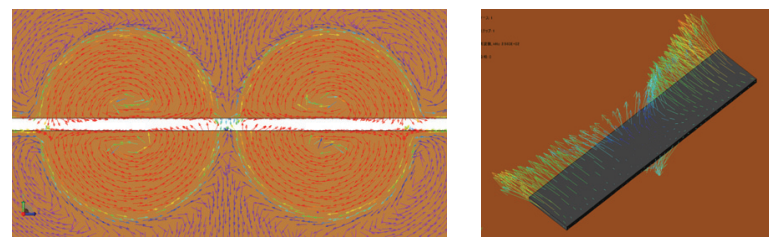

(c) 90 degree defect to the two adjacent exciting coils
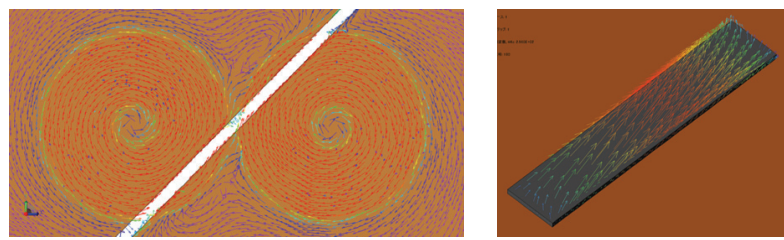

(d) 45 degree defect to the two adjacent exciting coils

Fig.3 Eddy currents in a plane copper plate and magnetic flux vectors in the ferrite bar.

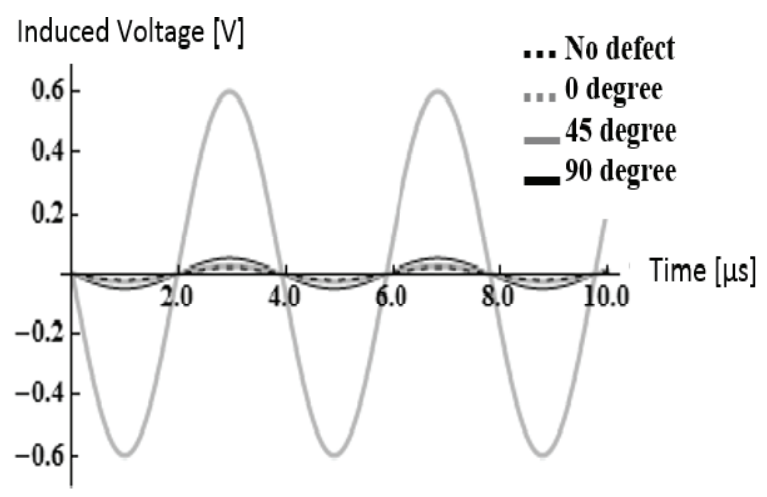

Fig.4 Induced voltages in the sensing coil.

銅板中に欠損が存在しない場合，Fig.3(a)左図に示す 渦電流が流れる。渦電流よって生じる磁束密度は検出 コイルの面に対し平行方向のみであるため Fig.3(a)右 図に示す方向となる。したがって欠損が存在しない場 合，検出コイルに誘起電圧は発生しない。

Fig.3(b)左図は $2 \mathrm{~mm}$ の幅の欠損が検出コイルに対し 0 度に配置された場合の渦電流分布である。渦電流は 欠損に沿う方向に流れるが，検出コイルの面に垂直の
磁界を生む成分は流れないためフェライトコア内の磁 束密度はFig.3(b)右図のようになる。0 度の場合も検出 コイルに誘起電圧は発生せず，欠損を検知することは 難しい。

Fig.3(c)左図に欠損が検出コイルに対し 90 度に配置 した場合の渦電流分布を示す。銅板中の渦電流は久損 によって妨げられ検出コイルの面に垂直に磁界を作る 方向に流れる。しかしながら，欠損の両端で発生する 渦電流は互いに打ち消し合う方向に流れるためフェラ イトコア内の磁束密度は垂直方向に発生しない (Fig.3(c)右図)。

Fig.3(d)左図に欠損が検出コイルに対し 45 度に配置 した場合の渦電流分布を示す。渦電流は欠損沿いに流 れ，検出コイルに垂直成分を含む磁界を作る。Fig.3(d) 右図に示すように検出コイルを貫く方向に磁束が発生 するため，検出コイルに誘起電圧が発生する。

また Fig.3(a)-(d)における検出コイルの誘起電圧を Fig.4 に示す。Fig.4 より久損が 45 度の場合, 高い誘起 電圧が発生し欠損の有無を識別できることがわかる。 検出信号の位相情報からも同様に欠損識別が原理的に 可能と考えられるが，これに関する議論は検討課題と して別の機会に述べたい。

\section{3 平面型のコイルの最適設計}

\section{1 最適設計法}

現在の工業製品の設計法では，過去の経験や実地試 験によって最適なモデルが決定されているため，新た に開発された製品に対する設計では過去の経験が無く 実地試験による手間が掛り多くの労力が必要となる。

開発された平面型のコイルは二個の励磁コイルとコアに 磁性体を持つ検出コイルから構成されるため, 検出感度は各 コイルの大きさに依存する。それゆえ, 平面型めコイルの形 状の最適設計には Fig.5 に示すように励磁コイルの直径 $\varphi$ を 基準とし $2 つ の$ 励磁コイル間の距離 $\mathrm{D}$ (検出コイルの直径), 検出コイルのコイル長 L を変化させた場合の検出感度を有 限要素法により算出する。ただし, 励磁コイルおよび検出コ イルの厚さは一定值とし, 検出コイルの直径は 0.9D とする。 これは平面型めコイルにおいては励磁・検出コイルの厚さは, 実用的にフィルムで作成するため, 励磁コイル間距離 D や検 出コイル長 L の変化と比較して十分短く, 感度に大きな影響 を与えないと仮定する。 


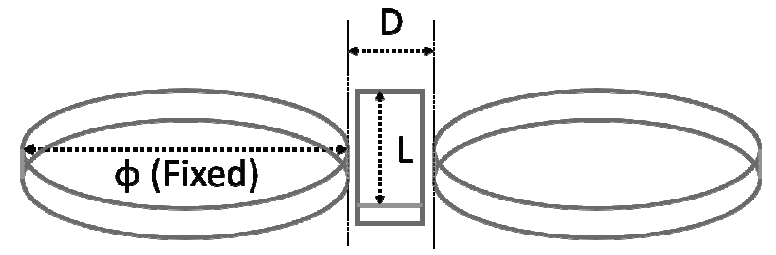

*A thickness of exciting coil and sensing coil is fixed value.

Fig.5 Schematic diagram of the flat $\infty$ coil optimization.

励磁コイルの直径に対する励磁コイル間の距離の 比を R 比として(1)式に, 励磁コイルの直径に対する検 出コイル長の比を L 比として(2)式に定義する。

$$
\begin{aligned}
& R \text { 比 }=D / \phi \\
& L \text { 比 }=L / \phi
\end{aligned}
$$

各形状での計算結果から $\mathrm{R}$ 比と L 比の近似関数を導 出し最適值を算出する方法を試みる。この方法では全 ての試行計算結果から近似関数を求めるため, 試行計 算結果を無駄にすることがなく最適が可能とされる。

\section{2 有限要素法による平面型のコイルの最適計算}

平面型のコイルの形状の最適設計には Table. 2 に示 す通り励磁コイルの直径 $10 \mathrm{~mm}$ を基準とし， $\mathrm{R}$ 比， $\mathrm{L}$ 比を 0.1 から 1.0 まで 0.1 刻みに変化させた場合におけ る，計 100 個のオフセット信号(Offset signal)O に対す る検出信号 (Senseful Signal)S の比(Senseful to offset signal Ratio, 以後, SO 比または SOR と略記) を有限 要素法により算出する。

励磁コイルに対する検出コイルの比率を求めるた め, 実装するコイルの幾何学的寸法は, 銅, S45C (鉄),

SUS304 から成る $100 \mathrm{~mm} \times 100 \mathrm{~mm} \times 10 \mathrm{~mm}$ の板状の被検

Table.2 Various constants used in the flat $\infty$ coil optimization.

\begin{tabular}{lr}
\hline \multicolumn{2}{c}{ Exciting coil } \\
\hline Coil outer diameter & $10 \mathrm{~mm}$ \\
Coil inner diameter & $2 \mathrm{~mm}$ \\
Coil length & $0.2 \mathrm{~mm}$ \\
Number of turn & 80 \\
Input current(effective value) & $300 \mathrm{~mA}$ \\
Frequency & $256 \mathrm{kHz}$ \\
\hline \multicolumn{2}{c}{ Sensin coil } \\
\hline Coil cross-section area (vertical) \\
Coil cross-section area (horizontal) \\
\multicolumn{2}{c}{$0.5 \mathrm{~mm}$} \\
Coil length & $1 \mathrm{~mm} \sim 10 \mathrm{~mm}$ \\
Number of turn & $1 \mathrm{~mm} \sim 10 \mathrm{~mm}$ \\
Axis core & 100 \\
\multicolumn{2}{c}{ MnZn/ferrite } \\
\hline
\end{tabular}

査対象上に長さ $20 \mathrm{~mm}$, 幅 $0.5 \mathrm{~mm}$, 深さ $1.0 \mathrm{~mm}$ の欠損 を探査目標として決定する。検出信号 S は，探査目標 久損を検出コイルに対し 45 度に配置した場合に発生 する誘起電圧である。

Fig. 6(a)-(c) が計算結果である。計算結果より全検査 対象において $\mathrm{R}$ 比が低く, L 比が 0.5 から 0.6 の付近 においてピーク值を持ち，最適な比率があることがわ かる。また Fig.6(b)の S45C において多くの”山”ができ たのは，鉄が強磁性体である故，非線形的な磁気飽和 が起こっているからであると考えられる。

また，本論文で $10 \times 10$ の 100 個のデータベースを構 築した理由として，最初は最も大きな範囲 $2 \times 2$ から出 発し，4×4 と徐々に増やしてデータベースを構築した 結果, 何れの被検査対象に対しても $10 \times 10$ 程度で最大 值の存在が明確となったからである。これ以上の初期 值を用意しても実用的に設計するのが困難と考えられ る。

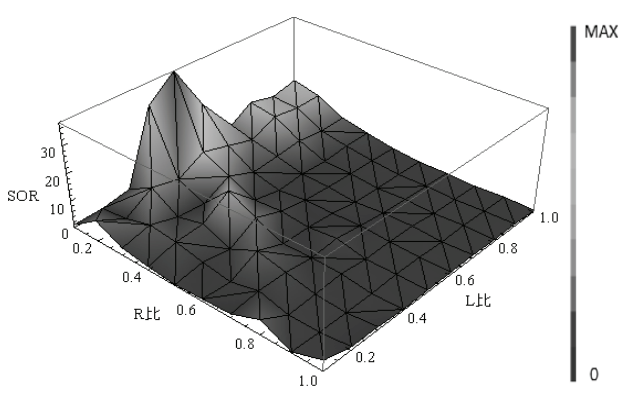

(a) Copper

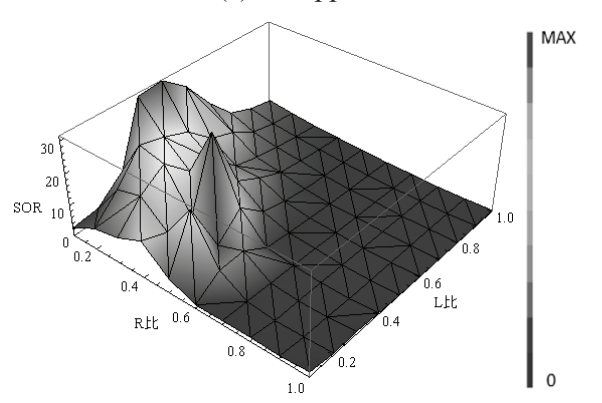

(b) $\mathrm{S} 45 \mathrm{C}$

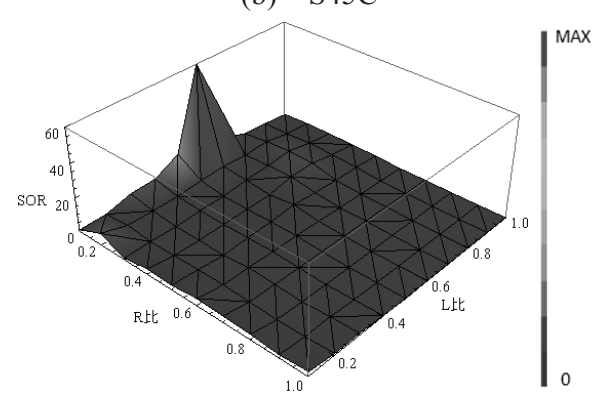

(c) SUS304

Fig.6 SOR distribution by FEM simulations. 


\section{3 ベき級数関数を用いた最適設計}

Fig.7 で求めた R 比，L 比に対する SO 比を表すため に, 式(3)の二変数 $\mathrm{R}$ と L についての $\mathrm{n}$ 次べき級数によ る近似を行う。

$$
\begin{gathered}
f(R, L)=a_{0}+a_{1} R+a_{2} L+a_{3} R L+a_{4} R^{2}+a_{5} L^{2}+ \\
\ldots+a_{m-1} R^{n}+a_{m} L^{n}
\end{gathered}
$$

式(3)の係数 $a_{0}, a_{1}, a_{2}, \ldots, a_{m}$ は最小自乗法で決定され る。すなわち, 式(3)の係数を要素とするべクトル A は 式(4)で与えられる。

$$
\mathbf{A}=\left[\mathbf{C}^{T} \mathbf{C}\right]^{-1} \mathbf{C}^{T} \mathbf{Y}
$$

ここで，上添え字”T”は行列の転置を示し， ベクトル A， Y，行列 C はそれぞれ(5)-(7)式で与えられる[4]。

$$
\begin{aligned}
& \mathbf{A}=\left[\begin{array}{lll}
a_{0} & a_{1} \cdot a_{m}
\end{array}\right]^{T} \\
& \mathbf{Y}=\left[f\left(R_{0.1}, L_{0.1}\right) f\left(R_{0.2}, L_{0.1}\right)\right. \\
& \left.f\left(R_{0.1}, L_{0.2}\right) \cdot f\left(R_{1.0}, L_{1.0}\right)\right]^{T}
\end{aligned}
$$

$\mathbf{C}=\left[\begin{array}{ccccccccc}1 & R_{0.1} & L_{0.1} & R_{0.1} L_{0.1} & R_{0.1}^{2} & L_{0.1}^{2} & \cdot & R_{0.1}^{n} & L_{0.1}^{n} \\ 1 & R_{0.2} & L_{0.1} & R_{0.2} L_{0.1} & R_{0.2}^{2} & L_{0.1}^{2} & \cdot & R_{0.2}^{n} & L_{0.1}^{n} \\ 1 & R_{0.1} & L_{0.2} & R_{0.1} L_{0.2} & R_{0.1}^{2} & L_{0.2}^{2} & \cdot & R_{0.1}^{n} & L_{0.2}^{n} \\ \cdot & \cdot & \cdot & \cdot & \cdot & \cdot & \cdot & \cdot & \cdot \\ 1 & R_{1.0} & L_{1.0} & R_{1.0} L_{1.0} & R_{1.0}^{2} & L_{1.0}^{2} & \cdot & R_{1.0}^{n} & L_{1.0}^{n}\end{array}\right]$ (7)

式(3)-(7)で求めた近似関数を Fig. 7 に示す。べき級数 の次数について試行錯誤の結果, 8 次関数までで Fig.7 の結果が表現でき, Fig.7 がその結果である。

よって，本論文では 8 次関数近似を採用した。さら に求めた関数から SO 比が最大值を取る值は, 全検査 対象において R 比が 0.10 は同一, L 比が銅で $0.48, \mathrm{~S} 45 \mathrm{C}$ で 0.47, SUS304 で 0.59 であることが判明した。この 方法では, 全ての試行計算結果からべき級数の近似関 数を求めるため, 試行計算結果を無駄にしない。被検 査対象の材料が既知の場合，この手法による最適設計 が有効である。

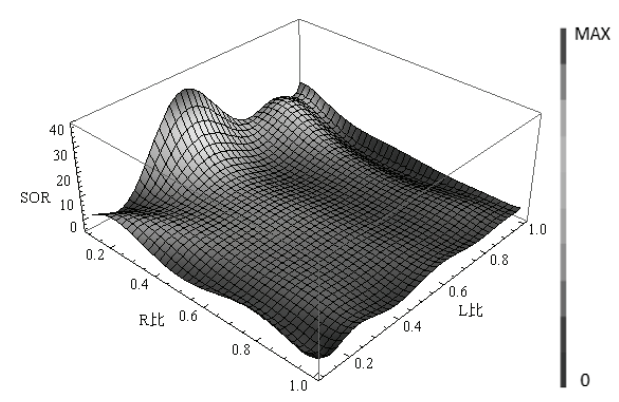

(a) Copper

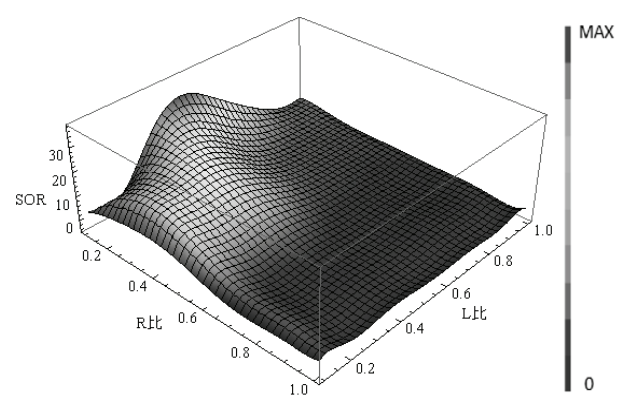

(b) $\mathrm{S} 45 \mathrm{C}$

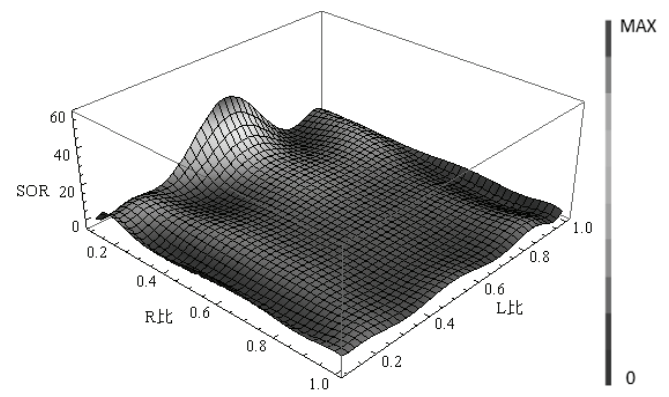

(c) SUS304

Fig.7 Approximate SOR distribution by Power series.

\section{4 畳み込み演算を用いた最適設計}

ベき級数関数を用いた最適設計では各検査対象にお ける最適値のみを算出した。ここでは Fig.6(a)-(c)に示 寸各検査対象の $10 \times 10$ のデータを正規化し，それぞれ を畳み込み演算して全検査対象に対する平面型めコイ ルの最適設計を試みる。この手法はフィルタの役割を 果たし, 全検査対象における最適值のみを明確に判断 するために行う。正規化は測定した $10 \times 10$ 点の SO 比 の最大となる值で 100 個のデータを割り，0 から 1 の 值にする。次に正規化された銅，S45C, SUS304 の值 を掛け算する。值の大きい SO 比は 1 に近い值が残る が，小さい值の SO 比は積の計算によって 0 に近づき フィルタの役割を行う。

Fig.8に結果を示す。すべての検査対象同士を畳み込 み演算するとピーク值が明確に一点に集中した。畳み 込夕演算を行い算出された三材料に対する最適設計值 
は R 比が 0.1，L 比が 0.6 となる。Fig.7 中のそれぞれ の検査対象に対する $\mathrm{SO}$ 比分布で $\mathrm{R}$ 比が 0.1 , L 比が 0.6 の座標值における SO 比とそれぞれの材料に対する 最大 SO 比との差が誤差に対応し, それぞれの最大 SO 值に対する割合で書けば，䛊差は銅に対して 44.1\%， 鉄に対して $18.49 \%$ ，SUS に対して $0 \%$ となる。

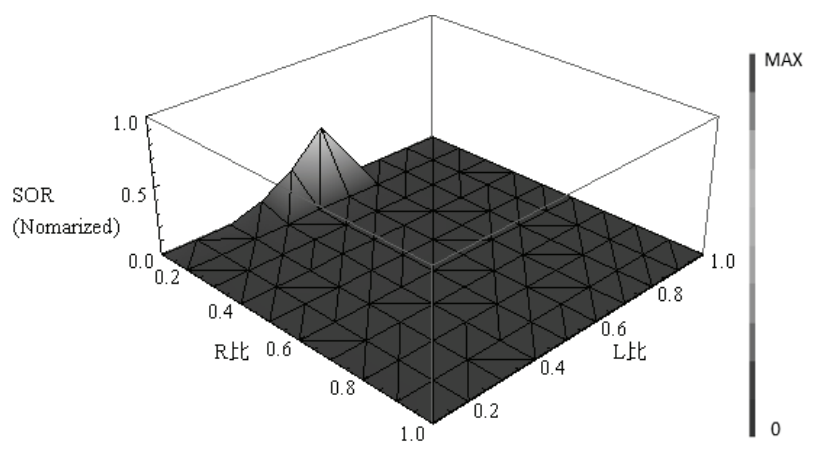

Fig.8 SOR distribution by convolution operation.

また，筆者は今日の自動車やプラントを構成する金 属部品の大多数が銅，鉄，ステンレス鋼であるという 背景から，本論文で選択した三材料が一般的であるた め，畳夕込み演算を用いた平面型めコイルの最適な形 状を求める際には,この三材料で十分であると考えた。

\section{5 結言}

本稿は平面型のコイル渦電流センサの最適設計法 について提案し， のコイルの検出感度が最大となる励 磁コイルに対する励磁コイル間距離と検出コイル長の 比率を決定した。

平面型のコイルのコイル配置および寸法は有限要 素法によるシミュレーション結果から決定され，コア に磁性体を持つ検出コイルを励磁磁界分布へ可能な限 り影響しない二個の励磁コイルの間に配置する。この ため，励磁コイルに対する検出コイルの位置と大きさ が検出感度に依存し，最適設計において極めて重要な 要素となる。

本論文では有限要素法で得られたシミュレーショ ン結果からべき級数を用いた近似関数を導出し，その 近似関数から銅・S45C・SUS304 におけるセンサコイ ルの最適形状を求めた。本論文では, 誘起電圧の信号 強度について論じたが，位相についても適用すること は可能である。べき級数近似関数法は，全ての試行計 算結果から近似関数を求めるため, 試行計算結果を無 駄にすることがない最適設計の一方法と位置づけられ る。べき級数を用いた最適設計が各検査対象に対する 最適設計であったのに対し，全検査対象に対する平面 型œコイルの最適設計を畳み込み演算によって試みた。 その結果, SO 比が最も高いピーク值が現れこの比率

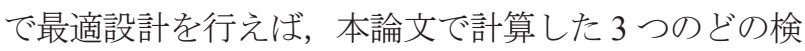
査対象においても感度が高い平面型めコイルを作成す ることができる。

(2015 年 4 月 30 日受付)

\section{参考文献}

[1] I.Marinova, S.Hayano and Y.Saito, Ployphase eddy current testing, Journal of Applied Physics, Vol. 75, No.10, pp. 5904-5906, 1994.

[2] N.Burais and A.Nicolas, Electromagnetic field analysis in remote field eddy current testing systems, IEEE Transactions on Magnetics, Vol.25, No.4, pp.3010-3012, 1989.

[3] S.McFee and J.P.Webb, Automatic mesh generation for h-p adaption, IEEE Transactions on Magnetics, Vol.29, No.2, pp.1894-1897, 1993.

[4] J.Kawazoe and Y.Saito, Fluctuation Frequency Analysis of the Barkhausen Signals Under Static and Dynamic Stresses, IEEE Transactions on Magnetics, Vol.49, No.5, pp.1997-2000, 2013.

[5] 菊地原弘基, 齊藤兆古, 大内学, 茂木秀夫, 及川芳朗, のコイル型渦電流センサの最適設計に関する考察, 日本 AEM 学会誌, Vol. 22, No.2, pp. 170-175, 2014 